Article

\title{
Reducing Vulnerability to Desertification by Using the Spatial Measures in a Degraded Area in Thailand
}

\author{
Saowanee Wijitkosum
}

Environmental Research Institute, Chulalongkorn University, Phayathai Road, Pathumwan, Bangkok 10330, Thailand; w.m.saowanee@gmail.com or saowanee.w@chula.ac.th; Tel.: +66-0218-8137

Received: 18 December 2019; Accepted: 6 February 2020; Published: 10 February 2020

check for updates

\begin{abstract}
The process of desertification is complex, involving interaction between many factors, both environmental and anthropogenic. However, human activities, especially from land-use change and inappropriate land use, are the most influential factors associated with the desertification risk. This study was conducted in Huay Sai, a degraded land in Thailand. The Environmentally Sensitive Area Index (ESAI) model incorporating Geogracphic Information System (GIS) was applied to investigate and map the desertification sensitivity area. The study aimed to analyze and assess measures to reduce the desertification risk. This study emphasized three group factors with nine subcriteria influencing desertification risk: soil (texture, fertility, drainage, slope gradient, and depth), climatic (precipitation and aridity index), and vegetation factors (land use and soil erosion). In terms of the required spatial measures to reduce the desertification vulnerability, policy and defensive measures that were closely related to drought and desertification of the area were considered. Three main measures covering soil and water conservation, soil improvement, and reforestation were implemented. The area development and restoration plans have been implemented continuously. The study found that $47.29 \%$ of the Huay Sai area was at a high risk, with a further $41.16 \%$ at a moderate risk. Implementation of three measures indicated that desertification risk was significantly decreased. Addressing the causes of the highest risk areas could help reduce the overall desertification risk at Huay Sai, where most areas would then be at either a moderate $(61.04 \%)$ or low $(32.43 \%)$ desertification risk with no severe- or high-risk areas. The success of the area restoration is from the formulation of a restoration and development plan that understands the local conditions. Moreover, the plan integrated the restoration of the soil, forests, and water together in order to restore the ecosystem so that the implementation was able to solve problems directly.
\end{abstract}

Keywords: desertification; spatial measure; ESAI; MEDALUS; land degradation

\section{Introduction}

Many parts of the world have been suffering from desertification, which has doubled its adverse influences in recent years. According to the United Nations Convention to Combat Desertification (UNCCD), desertification is land degradation resulting from climatic variations and human activities in arid, semi-arid, and dry subhumid areas [1-3]. These areas are also categorized as drylands in which the ratio of annual precipitation to potential evapotranspiration falls within the range from 0.05 to $0.65[1,4]$. The UNCCD consequently defines affected countries in all parts of the world; as much as $41.30 \%$ of the total global land area is considered drylands. Although the world's drylands continue to be the most vulnerable and are menaced by desertification and land degradation, land degradation is a global phenomenon, with $78 \%$ of total degraded land located in terrestrial ecosystems other than drylands.

Moreover, apart from this definition, desertification is typically used as a catch-all term for land degradation in water-scarce parts of the world. The condition leads to temporary or permanent decline in 
quality of soil, vegetation, water resources, or wildlife. The four major drivers behind land degradation are overgrazing (35\%), deforestation $(30 \%)$, agricultural activities $(28 \%)$, and overexploitation for biofuels (7\%) [3]. UNCCD also identified other key players that accelerate the land degradation process, including climate change, erosion by wind and/or water, soil deterioration from physical, chemical, and biological factors, and long-term vegetation loss [5]. The definitions may differ depending on their emphasis on ecological, meteorological, and human dimensions [6,7]. Many studies have suggested that the primary causes of desertification in recent years lie in human activities, land-use changes, and inappropriate land use $[4,8,9]$. These activities intensify and accelerate problems, which leads to land degradation [9-13]. The natural factors and human activities causing desertification are highly interrelated $[8,14]$.

Land is an important resource for food production and other ecological services, including biodiversity conservation, control of the hydrological system, cycling soil nutrients, and carbon sequestration. Desertification affects as much as one-sixth of the world [3]. In 1992, the United Nations Development Program (UNDP), to combat desertification and drought [1,3], sought to address the process of desertification in the long term, including climate change, soil erosion from wind and water, the distribution of soil salinity, the physical, chemical and biological deterioration of soil, and the loss of natural plant cover. As an outcome of interactions among many complex processes, desertification is often challenging to quantify. The land degradation and desertification affect very large areas of the world and cause a loss of land productivity [6,7], soil fertility decline [13], and decrease in soil quality [11] and land potential [12]. Previous research has shown that deterioration of soil results in abandonment of agricultural land. This abandonment has environmental consequences such as changes in water resources, soil erosion, soil properties, vegetation cover, and soil and water losses $[15,16]$. Addressing current and future issues on land degradation is not just a matter for each nation. The United Nations adopted the 17 Sustainable Development Goals (SDGs) of the 2030 Agenda for Sustainable Development. For SDGs 15: Life on Land, the UN has defined 12 Targets and 14 Indicators. The target 15.3: "End desertification and restore degraded land", states these goals to achieve by 2030: combat desertification, restore degraded land and soil, including land affected by desertification, drought, and floods, and strive to achieve a land degradation neutral world [17,18]. In reaching the desired sustainable situation as described in SDG 15.3, good land management, land use planning, and effectiveness of land restoration play an essential role. Land restoration and rehabilitation and land use planning can have significant cobenefits for sustainable development. Land use planning is a tool for sustainable land consumption.

Land degradation and desertification are complex problems, so solving them requires systematic thinking and integrated solutions. Although these problems are global in scale, solving problems at the national or local level is important. There are four major drivers to achieving land degradation neutrality and desertification combating, including governance, local peoples, economic and private sectors, and effective land management and planning. Local action plays an important role in combating the land degradation and desertification. The governance or responsible organizations must understand the problems of their area and prioritize the problem for setting a clear goal, implementing the plan, and monitoring, evaluating, and modifying it. By raising awareness for people and education at all levels, it is important to fix the problem in the long run, which will cause sustainability in the consumption of natural resources [17,18]. Moreover, according to sustainable production of goods and services, economic sectors need to calculate an environmental cost. The nature-based solutions in land and water management, including soil-water system solutions, and landscape solutions, are effective tools for land restoration and degradation neutrality [17]. This solution can restore soil services, goods, and resources [16]. The nature-based soil and water conservation strategies are instruments for restoration of agricultural land abandonment [15].

Land degradation, drought, and desertification are three major problems that are affecting developing countries adversely, especially in food security and survival. UNCCD [3] emphasizes the importance of eradicating land degradation and desertification and combating desertification as 
top priorities for global sustainable development. At this point, UNCCD focuses on restoring bare land, reforestation, and drafting drought preparedness policies and implementing them worldwide. However, it is crucial to understand and evaluate the pre-existing underlying problems, especially in terms of spatial data. The roots of the problems vary yet are interrelated. They may involve spatial dimensions or socioeconomic dimensions. Moreover, it is important to assess and monitor implemented mitigations that were put in place to battle soil degradation and desertification to ensure its sustainable success.

Many mathematical models have been proposed as methods to predict desertification risk and desertification sensitivity of an area. Mediterranean Desertification and Land Use (MEDALUS) is one of the most well-known models to quantify the sensitivity of land to desertification and detect the most vulnerable areas. The MEDALUS model [19] is developed to identify environmentally sensitive areas (ESAs) by using the Environmentally Sensitive Area Index (ESAI). The ESAI has proven to be a successful tool to detect areas at the highest risk of land degradation [20-23]. The model also allows inclusion of new indicators and subindicators and can be adjusted to several levels of scale [22]. Ladisa et al. [23] reported that it is simple, robust, and widely applicable. According to these characteristics of the model, it has been widely used among researchers for assessing desertification risk in many countries in Asia such as Iran [24,25], Malaysia [26], and Thailand [4,9]. This method identified environmentally sensitive areas by using a number of indexes [22], where all the indexes were reinvestigated and adjusted to fit local conditions. Researchers often incorporate Geographic Information System (GIS) and remote sensing with ESAI, allowing the model to clearly depict the spatial problems of the study area, leading to more effective area management $[9,24,25]$.

According to the UNCCD, Thailand is classified as an affected country despite its monsoon climate. Thailand is an affected country according to Section 1 (a), (f), and (g) of the Convention [1] due to land degradation or desertification, with approximately 33.57 million hectares of agricultural areas having problematic soils [27]. Thailand is located in a tropical climate zone with high precipitation and high temperature throughout the year. Many parts of Thailand are considered as having a tropical wet-dry climate or tropical savannah climate (Aw). However, some areas are classified as dry subhumid areas in which the aridity index falls within the range from $0.51-0.65[9,27]$. These areas of the country, especially in the northeastern and western regions, often suffer from drought and land degradation [27]. Other problems associated with land degradation include aridity and soil deterioration or repeated droughts (Figure 1). If the problems persist, the areas will be at a higher risk of desertification. The projected changes in aridity index (the ratio of rainfall to Potential Evapotransiration (PET)), simulated over land by 27 CMIP5 climate models by 2100 under the RCP8.5 scenario, had shaded some parts of Thailand in red. This indicated that the areas are becoming drier, since the PET increased more than the rainfall ratio [28]. Phetchaburi and Prachub Kirikhan are the two provinces with the highest PET.

The Huay Sai area, Phetchaburi province, Thailand is a drought-affected area with land degradation, which makes it sensitive to desertification. The area has suffered from continuous deforestation, monocropping, and heavy use of agrochemicals, which have directly impacted soil fertility and soil texture. Droughts, low soil fertility levels, loss of surface soils, and fertile soil being turned into shale have all been reported $[29,30]$. These recurring problems put the Huay Sai area at a very high risk of desertification. Factors influencing drought and desertification in the Huay Sai area at a moderate to severe risk level include soil, climatic, and vegetation factors [4]. Although climatic factors contributing to desertification may be difficult to control, desertification caused by human activities can be limited through appropriate land use planning and regulation [6,7]. Therefore, reducing the drought and desertification risks is possible through appropriate local area management. At the same time, the process to enhance the capability to handle desertification risk, which is key to disaster risk reduction, should be implemented [1]. 
Many areas of Thailand have suffered from land degradation and drought. In terms of its treaty obligations, Thailand acceded to the UNCCD in June 2001 and agreed to be part of the global agreement to combat land degradation. Thailand's Land Development Department (LDD) is the National Focal Agency responsible for fulfilling the country's obligations under Sections 9 and 10 of the UNCCD by preparing and implementing the National Action Programme to Combat Desertification (NAPCD) of the Kingdom of Thailand. The NAPCD 2004-2008 included two groups of strategic issues. The first strategic issue prescribed development of basic infrastructure of soil and water resources for crop production. This strategic issue aims to promote suitable land uses as well as improve soil fertility and water resources. The second strategy aims to promote access to land development services for farmers. This strategic issue consists of two strategies for the enhancement of opportunity for farmers and communities to thoroughly access public services [27]. However, solving the environmental problems must take account of the local conditions where the topographical and sociological conditions of the local areas, which are different in terms of the nature of the problems concerned.

It is well-known that according to its location, Thailand is not in the area at risk of desertification. However, some parts of Thailand can be considered as an affected country by the aridity index. This research aims to point out that although the study area is not considered to be at desertification risk due to climate and geographic location, human activities have brought this area to drought and desertification risk. Moreover, the assessment of planning and mitigation to reduce the desertification risk is a dissemination strategy. The process involves integration between risk reduction strategies for manmade risks and spatial planning at the policy level. However, even though the implementation of the integrated process is crucial to the area in general, it has only been implemented in limited areas. Moreover, the implementation of the process was unclear and did not correspond to the spatial planning of the area. According to a report by the United Nations Office for Disaster Risk Reduction (UN/ISDR), there are gaps in five areas of disaster risk reduction. Three of the five challenging gaps are prioritizing disaster risk management, developing and strengthening the disaster risk assessment, and reducing the development risk factors [1]. Therefore, this research aimed to analyze and assess mitigations for the desertification vulnerability reduction in the Huay Sai area. The ESAI model with the GIS technique was applied to investigate the desertification risk. The results of this study will be distributed to local authorities for the planning, managing, and drafting of the policy for the area to help prevent desertification.

\section{Materials and Methods}

\subsection{The Study Area Description}

The major causes of desertification found in Thailand are: (a) climatic factors such as heavy rain that dissolves and translocates soil minerals during the monsoon period and seasonal droughts; (b) human activities such as land use without soil improvement plan, over-exploitation of land, and land use on steep-slope lands causing soil erosion and expansion of saline soils [27]. Moreover, Thailand has slightly less than 30 percent forest cover. Most of the forests are either restricted or relatively inaccessible mountainous areas [31]. Some areas of Thailand are facing severe drought and degradation of soil resources. Thailand has always experienced drought, which in many parts of Thailand is a redundant arid areas, which account for $18.69 \%$ of the area of Thailand. They are divided into severely repetitive arid (level 3) areas, which occur repeatedly 1-3 times/year (red areas), accounting for $13.50 \%$ of Thailand or $72.27 \%$ of redundant arid areas; moderate redundant drought (level 2) areas with a frequency of 4-5 times/year repeated drought (orange areas), and areas with low levels of redundant drought (yellow areas) frequency of occurrence of repeated drought 6-10 times/year (Figure 1). 


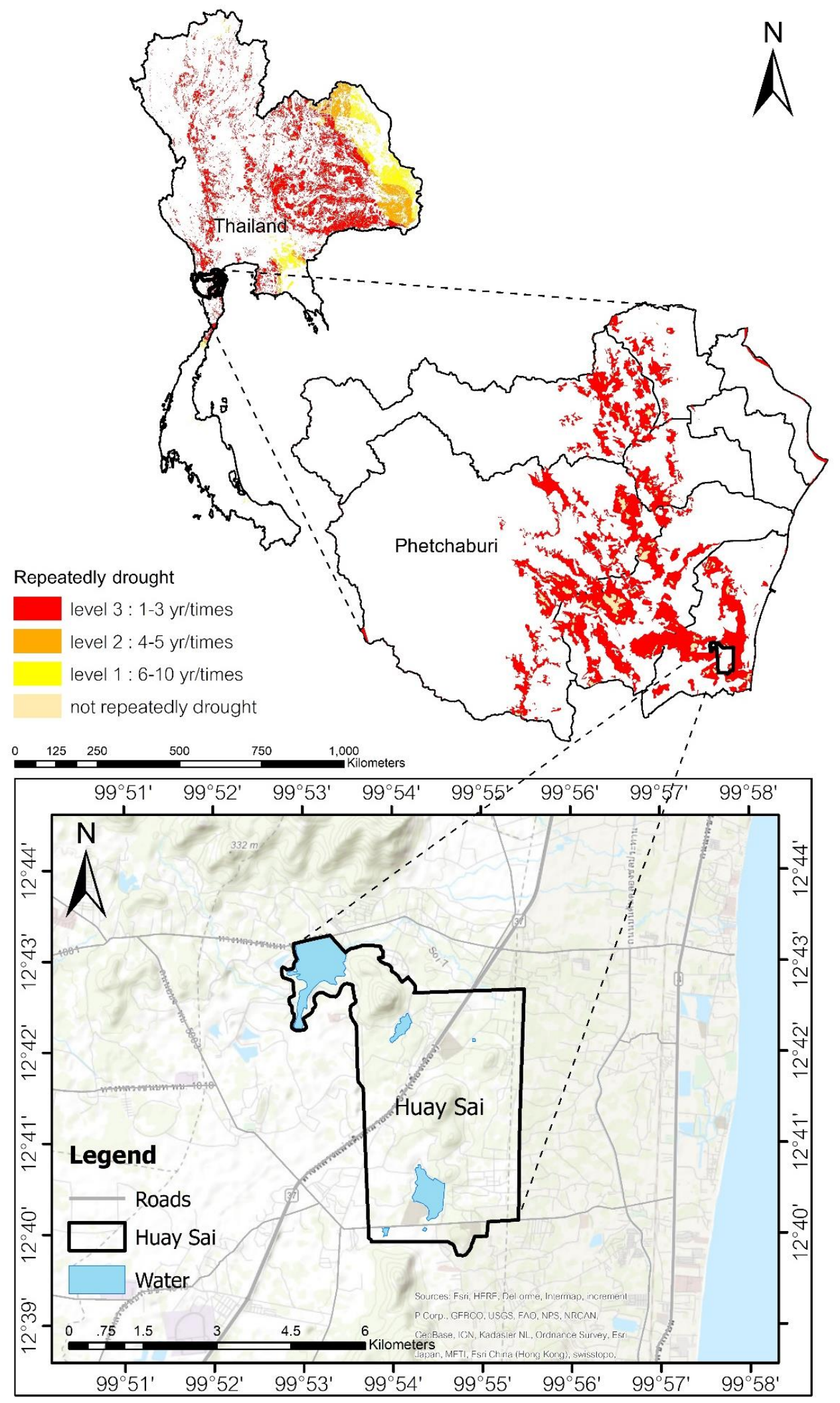

Figure 1. Huay Sai Area and the situation of drought in Thailand.

Huay Sai is located in Cha-am district, Phetchaburi province, Thailand (Figure 1). The study area, Huay sai, covers an area of approximately $18,414,600 \mathrm{~m}^{2}$ (1,841 ha). The area is mostly piedmont plateaus with a $2 \%-5 \%$ slope, an average rainfall of $954.8 \mathrm{~mm} / \mathrm{y}$ and an evaporation rate of $1711 \mathrm{~mm} / \mathrm{y}$ 
(over the last 30 y). Before 1946, Huay Sai was blessed with abundant resources, including soil, water, and diverse ecosystems. The forested area was a habitat for hog deer, an indigenous deer species, from which it derived its name "Huay Sai" (the creek of hog deer). However, the abundant resources were destroyed by human activities including using pesticides and deforestation for monocropping. Monocropping was a widespread practice, especially growing pineapples to feed the increasing demand from fruit-processing factories, but this led to an excessive use of agrochemicals and inappropriate land use. Moreover, no soil conservation measures were enforced, which led to severe land degradation. Thirty-seven years later, the land that was once rich with flora and fauna became uncultivable and barren. The topsoil was eroded and became no longer productive, resulting in a rapid change in the area conditions. The soil is infertile and hard, and it is impossible for plants to grow [30]. The soil texture has become sandy and acidic ( $\mathrm{pH} 3.3)$ with a very low level of organic matter (OM of 0.20) and nutrients. The ecosystem was destroyed and lacked rainfall. The annual precipitation was less than $600 \mathrm{~mm}$. The consequences of land degradation triggered desertification processes in the area and its vicinity. The inappropriate use of the soil has brought long-term impacts on the area's fertility.

In 1983, the late King Bhumibol Adulyadej paid a royal visit to the Huay Sai area and noticed the problems and stated, "If we leave this area alone, it will become a desert". This led to the establishment of the Huay Sai Royal Development Study Centre (HSRDSC) to restore the area, solve the environmental problems, and ensure sustainable development in the area [26]. The Huay Sai Royal Development Study Centre thus focuses attention on conducting studies and research on methods to develop deteriorated forests, control forest fires, develop water sources to increase moisture in the area, conduct a study on agricultural development program with an emphasis on means to seek participation from farmers in planting, and rehabilitating and maintaining forests while at the same time obtaining income and benefits from them.

\subsection{Analysis of the Factors Influencing Desertification of the Area}

The process of desertification is very complex and involves interactions among many factors, including both environmental and anthropogenic [13,32]. Many studies, such as $[4,8,9]$ have indicated that land degradation from human activities is the main cause of desertification. However, close interactions among various factors, including climate change, environmental factors, and human activities, also play significant roles.

In this study, the factors affecting the vulnerability to desertification of the Huay Sai area were divided into four factors and further subdivided into twelve subcriteria covering both environmental and anthropogenic factors. The first three factors were used to calculate the vulnerability to desertification, and the last one was used to assess the risk of desertification when the spatial measures for combatting the land degradation were implemented.

The first soil factor included the five subcriteria of the soil texture, fertility, depth, slope gradient, and drainage. Data on these soil properties were collected by the LDD. The soil quality was assessed in terms of the soil texture, fertility, depth, and drainage. Generally, the soil texture and depth are strongly affected by the parent material and climatic conditions. However, during the past few decades, human activities have had a major influence on the soil resources and soil system. These changes cause adverse impacts on plant growth and yields. Some areas have become extremely infertile and are no longer suitable for plants to grow, causing a lack of vegetation cover. If this continues unabated, the area will eventually become a desert [28]. The climatic factors, including precipitation and aridity index (AI), have a great impact on the soil depth through the processes of weathering and erosion. Besides, the climatic factors are also related to the water availability for planting. Analysis of precipitation over the last 30 y (1986-2016) was performed using the meteorological data from a meteorological station in the study area. Rainfall indexes were calculated using Rainfall Decile [33]. The AI was calculated from the equation P/PET, where the PET was calculated by multiplying the crop coefficient (Kc) with the reference evapotranspiration (ET0), the latter being estimated using the Penman-Monteith equation [34,35]. 
Vegetation factors were assessed in the two aspects of land use and soil erosion. Both factors are the results of human activities and have significant impacts on land utilization and soil resource $[10,11,36]$. Land-use change is one of the key factors leading to soil problems in the area, including the soil $\mathrm{pH}$, texture, properties, density, drainage, and fertility. Soil erosion was strongly affected by the precipitation intensity and slope gradient $[10,37,38]$. The soil erosion condition was assessed with the Universal Soil Loss Equation (USLE), which was adapted to suit Thailand's conditions and was validated by the LDD [11]. To investigate land use pattern in 2017, both remote sensing and field surveys were employed to interpret satellite images taken by Landsat 8TM (14 February 2017). The last factors are the management of the area, which includes the policy and measures of land-soil-water development, divided into three subcriteria of soil and water conservation, soil improvement, and reforestation.

\subsection{Assessment of the Vulnerability to Desertification}

The methodology used was based on the MEDALUS model, developed in a large project established by the European Commission [19]. The MEDALUS identifies regions that are ESAs using an ESAI to calculate indexes that lead to land degradation and, eventually, desertification. The model is flexible and allows one to adjust or change the number of indicators to be used for assessing the quality indexes. Therefore, users could add and adjust more spatial factors that fit the local condition.

In this study, the local indexes (subcriteria), which combine anthropogenic and environmental factors, were brought in and calculated using the ESAI model to obtain the desertification risk assessment of the Huay Sai area. It is aimed to develop a set of indicators to identify areas that are sensitive to desertification and subsequently the development of action plans to combat land degradation. The last indicator also includes land management measures to reduce the land degradation and desertification rate, known as the management of land factors [22]. Each factor is represented by an index that is calculated by the combination of subindexes.

Each index was applied using a quantitative classification scheme with scores ranging from 1 to 2 . A score of 1 (the best value) was assigned to areas with the lowest sensitivity, whereas a score of 2 (the worst value) was assigned to those areas with the highest sensitivity [8]. The score was assigned to the elements of a particular parameter in relation to their effect on the sensitivity to soil degradation and desertification processes as described by Kosmas et al. [19]. The classes and quality index for each factor adapted from LDD of Thailand and Sepehr et al. [22] are shown in Table 1.

The indicators were grouped and combined into four quality layers representing the soil (SQI), climate (CQI), vegetation (VQI) and management (MQI) quality indexes. The SQI and CQI provided a full picture of the environmental conditions, while the VQI provided the anthropogenic activities, and the MQI provided the results of the area management following the implemented policy of the organization (Table 2). The methodology approach of this study is shown in Figure 2.

An image processing system (ENVI) and GIS mapping software (ArcGIS 9.3) were the main tools used to compute indexes and generate the desertification risk factor Map. The data for all the four groups of the quality index were processed in a GIS environment to produce the four indicator maps.

These indicators are determined based on various subindicator maps. The environmental sensitivity indexes, obtained as the geometric mean, were used to compile the ESA maps to assess the extent of desertification. The maps were obtained using the Inverse Distance Weighting (IDW) deterministic interpolation techniques. The IDW function generates the interpolated surface by assigning values to unknown points from a weighted sum of values of known points. Each QI was calculated using the respective algorithm (Table 2) and was classified into the four major categories shown in Table 2. Each index was grouped into a different uniform class with a weighting factor assigned to each class, depending on its relative impact on the desertification, which, in turn, was related to the local environmental conditions. After assigning the weightings, the values of the QI for each elementary unit within a layer were obtained as the geometric average of the scores for the single indicators. 
Table 1. Classes and assigned weighting index for factors.

\begin{tabular}{|c|c|c|c|c|}
\hline Factor/ & Layer/ & \multirow{2}{*}{ Classes } & \multirow[t]{2}{*}{ Descriptions } & \multirow{2}{*}{ Quality Scores } \\
\hline Indicators & Sub-indicators & & & \\
\hline \multirow{21}{*}{ Soil } & \multirow{4}{*}{ Texture $^{\mathrm{a}}$} & Good & $\mathrm{L}, \mathrm{SCL}, \mathrm{SL}, \mathrm{LS}, \mathrm{CL}$ & 1 \\
\hline & & Moderate & SC, SiL, SiCL & 1.2 \\
\hline & & Poor & $\mathrm{Si}, \mathrm{C}, \mathrm{SiC}$ & 1.6 \\
\hline & & Very poor & S & 2 \\
\hline & \multirow{6}{*}{ Fertility } & Very low & High fertility at 15 points & 1 \\
\hline & & Low & High fertility at $13-14$ points & 1.2 \\
\hline & & Moderate & Moderate fertility at $11-12$ points & 1.4 \\
\hline & & Moderate & Moderate fertility at $9-10$ points & 1.6 \\
\hline & & High & Low fertility at $7-8$ points & 1.8 \\
\hline & & Severe & Low fertility at $5-6$ points & 2 \\
\hline & \multirow{3}{*}{ Drainage } & Good & Well-drained & 1 \\
\hline & & Moderate & Imperfectly drained & 1.2 \\
\hline & & Poor & Poorly drained & 2 \\
\hline & \multirow{4}{*}{ Slope gradient } & Gentle & $<6 \%$ & 1 \\
\hline & & Not very gentle & $6 \%-18 \%$ & 1.2 \\
\hline & & Abrupt & $18 \%-35 \%$ & 1.5 \\
\hline & & Very abrupt & $>35 \%$ & 2 \\
\hline & \multirow{4}{*}{ Soil depth } & Very deep & Soil thickness $>100 \mathrm{~cm}$ & 1 \\
\hline & & $\begin{array}{l}\text { Moderately } \\
\text { deep }\end{array}$ & Soil thickness $50-100 \mathrm{~cm}$ & 1.2 \\
\hline & & Not deep & Soil thickness $25-50 \mathrm{~cm}$ & 1.5 \\
\hline & & Very thin & Soil thickness $<25 \mathrm{~cm}$ & 2 \\
\hline \multirow{10}{*}{ Climatic } & \multirow{5}{*}{ Aridity index } & Very low & $0.65-1.00$ & 1 \\
\hline & & Low & $0.50-0.65$ & 1.2 \\
\hline & & Moderate & $0.20-0.50$ & 1.5 \\
\hline & & High & $0.05-0.20$ & 1.7 \\
\hline & & Severe & $<0.05$ & 2 \\
\hline & \multirow{5}{*}{ Precipitation } & Very high & $1833-2592 \mathrm{~mm}$ & 1 \\
\hline & & High & $1436-1833 \mathrm{~mm}$ & 1.2 \\
\hline & & Moderate & $1194-1436 \mathrm{~mm}$ & 1.5 \\
\hline & & Low & $1022-1194 \mathrm{~mm}$ & 1.7 \\
\hline & & Very low & $<1022 \mathrm{~mm}$ & 2 \\
\hline \multirow{10}{*}{ Vegetation } & \multirow{5}{*}{ Land use } & & Evergreen forest & 1 \\
\hline & & & Fruit trees and perennial plants & 1.2 \\
\hline & & & Natural grasslands & 1.5 \\
\hline & & & Communities and built-up areas & 1.7 \\
\hline & & & $\begin{array}{c}\text { Field crop }>70 \% \text {, deciduous forest }> \\
70 \% \text { and bare land }\end{array}$ & 2 \\
\hline & \multirow{5}{*}{ Soil erosion } & Very low & $0-1,250,000 \mathrm{~kg} \mathrm{~km}^{-2} \mathrm{y}^{-1}$ & 1 \\
\hline & & Low & $1,250,000-3,150,000 \mathrm{~kg} \mathrm{~km}^{-2} \mathrm{y}^{-1}$ & 1.2 \\
\hline & & Moderate & $3,150,000-9,400,000 \mathrm{~kg} \mathrm{~km}^{-2} \mathrm{y}^{-1}$ & 1.5 \\
\hline & & High & $9,400,000-12,500,000 \mathrm{~kg} \mathrm{~km}^{-2} \mathrm{y}^{-1}$ & 1.7 \\
\hline & & Very high & $>12,500,000 \mathrm{~kg} \mathrm{~km}^{-2} \mathrm{y}^{-1}$ & 2 \\
\hline \multirow{10}{*}{ Management } & \multirow{4}{*}{$\begin{array}{l}\text { Water resource and } \\
\text { soil conservation } \\
\text { and development }\end{array}$} & Complete & $>75 \%$ of the poor soil quality area & 1 \\
\hline & & Good & $50 \%-75 \%$ of the poor soil quality area & 1.2 \\
\hline & & Moderate & $25 \%-50 \%$ of the poor soil quality area & 1.5 \\
\hline & & Incomplete & $<25 \%$ of the poor soil quality area & 2 \\
\hline & \multirow{4}{*}{ Soil amelioration } & Complete & $>75 \%$ of the agricultural area & 1 \\
\hline & & Good & $50 \%-75 \%$ of the agricultural area & 1.2 \\
\hline & & Moderate & $25 \%-50 \%$ of the agricultural area & 1.5 \\
\hline & & Incomplete & $<25 \%$ of the agricultural area & 2 \\
\hline & \multirow{2}{*}{ Reforestation } & High & $>50 \%$ of the bare land & 1 \\
\hline & & Moderate & $<50 \%$ of the bare land & 2 \\
\hline
\end{tabular}

a Sand (S); Loamy sand (LS); sandy loam (SL); loam (L); silt loam (SiL); silt (Si); sandy clay loam (SCL); silty clay loam (SiCL); clay loam (CL); sandy clay (SC); silty clay (SIC); and clay (C). 
Table 2. Environmental properties related to desertification sensitivity indexes.

\begin{tabular}{ccc}
\hline Quality index & Properties/Descriptions & Algorithms \\
\hline SQI & $\begin{array}{l}\text { Ist: soil texture index } \\
\text { Isf: soil fertility index } \\
\text { Isdt: soil depth index } \\
\text { Isg: slope gradient index } \\
\text { Isdn: soil drainage index }\end{array}$ & $S Q I=(\text { Ist } \times I s f \times I s d t \times I s g \times I s d n)^{1 / 5}$ \\
\hline CQI & $\begin{array}{c}\text { Ipt: precipitation index } \\
\text { Iai: AI }\end{array}$ & $C Q I=(I p t \times I a i)^{1 / 2}$ \\
\hline VQI & $\begin{array}{l}\text { Ilu: land use index } \\
\text { Ise: soil erosion index }\end{array}$ & $V Q I=(I l u \times I s e)^{1 / 2}$ \\
MQI & $\begin{array}{c}\text { Isw: soil and water conservation index } \\
\text { Isi: soil improvement index } \\
\text { Irf: reforestation index }\end{array}$ & $M Q I=(I s w \times I s i \times I r f)^{1 / 3}$ \\
\hline
\end{tabular}

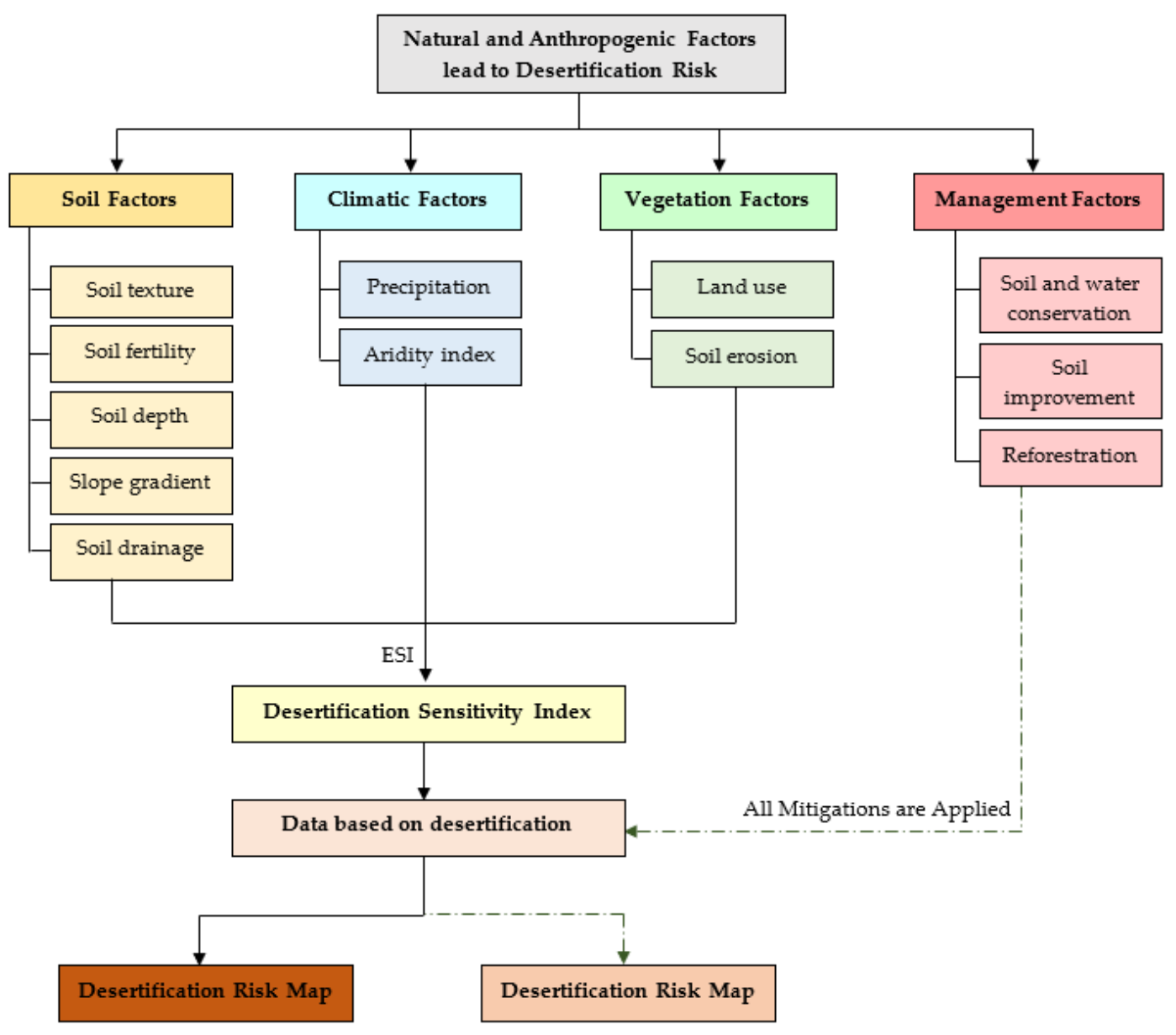

Figure 2. Methodology approach.

\subsection{Mapping the Desertification Sensitivity Area}

The QIs were used to compute a desertification sensitivity index (DSI) and then generate a map of the desertification-sensitive areas $[8,20]$ by analyzing both spatial and attributes data using the ArcGIS 10.3 software. The DSI of Huay Sai was computed from Equation (1), which was constructed from the MEDALUS approach [19].

$$
D S I=(S Q I \times C Q I \times V Q I \times M Q I)^{1 / 4}
$$

Based on the estimated DSI values, the scoring and classification categories of the desertification sensitivity in the study area are described in Table 3. 
Table 3. Ranges and classes of desertification sensitivity index.

\begin{tabular}{cccc}
\hline Class & DSI & Sensitivity to Desertification & Risk/Condition \\
\hline 1 & $1.00-1.22$ & Low & Low \\
2 & $1.23-1.37$ & Medium & Moderate \\
3 & $1.38-1.53$ & High & High \\
4 & $1.54-2.00$ & Very high & Severe \\
\hline
\end{tabular}

\section{Results and Discussion}

\subsection{Desertification Risk Level and Risk Factors}

The soil in the study area has a very poor texture and structure. The dominant soil texture $(62.5 \%$ of the total area) is coarse-textured sandy soil with a very poor water holding capacity and soil moisture. The soil thickness in most of the area $(90.2 \%$ ) is moderately deep (range $50-100 \mathrm{~cm}$ ) with a low to very low soil fertility, very strongly acidic ( $\mathrm{pH}$ at 3.3$)$, and with a very low OM (0.205-2.48\%). These soil properties adversely affect the cropping (vegetative cover) and moisture level in the soil leading to Huay Sai suffering from droughts for a long period of time. These very inferior soil properties result from changing the land use from a forest area to monocropping with excessive use of agrochemicals over a long time.

This result corroborated Wijitkosum and Yolpramote [29], which studied the soil properties in the Huay Sai area. The research found that most soil in the area is strongly acidic with low fertility. From the soil factor analysis, it is concluded that the soil texture affected the desertification risk at a severe level. In addition, the soil fertility influenced the desertification risk at a high to severe level, while soil erosion had a low or zero correlation with the desertification risk in the area. The map of the desertification risk factors is shown in Figure 3.

Most of the Huay Sai area (93.2\% of the total area) has an AI range from $0.65-1.00$, which indicates that the AI affected the desertification risk at a very low impact level, while conversely the precipitation level strongly influences the desertification risk of the area at a severe level. Interpretation of the 2017 Landsat 8 images indicates that evergreen forest comprised $88.1 \%$ of the study area, with $8.49 \%$ agricultural, $3.11 \%$ community, $0.26 \%$ bare land, and $6.57 \%$ water body areas. The soil erosion assessment showed that the majority of the study area $(96.6 \%$ of the total area) was characterized by a very low soil erosion risk $\left(0-1,250,000 \mathrm{~kg} \mathrm{~km}^{-2} \mathrm{y}^{-1}\right)$. However, virtually the entire central plain area was found to be at a moderate risk of soil erosion.

\subsection{Desertification Sensitivity in Huay Sai Area}

From the desertification risk assessment of this area, it was found that $47.29 \%$ of the total area was a high desertification risk area, followed by medium $(41.16 \%)$, low $(4.78 \%)$ and severe $(0.26 \%)$ risk areas. However, the water bodies, which accounted for around $6.53 \%$ of the total area, were not included in the calculation (Figure 4). The high desertification risk areas were dispersed and located especially in the central and the southern parts of the study area. Low-risk areas were mainly found in the north of the study area nearby water resources. This is consistent with a previous study [4] on the desertification risk in the area using the same factors, where, in 2010, most of the study area $(77.24 \%)$ was at a high risk of desertification, while $0 \%, 14.29 \%$ and $0.47 \%$ were at a medium, low and severe desertification risk, respectively. Thus, over the last 17 years, the areas of high and severe desertification risk have decreased, becoming medium- and low-risk areas.

With respect to the effect of each factor on the desertification risk in the area, the critical factor was found to be the soil resources and land use, consistent with previous studies [4]. Those previous studies reported that the soil texture and fertility had high and a medium to very high levels of effect on the desertification risk, respectively. Similar to the soil texture, the land use had a medium to very high level of effect on the desertification risk. 


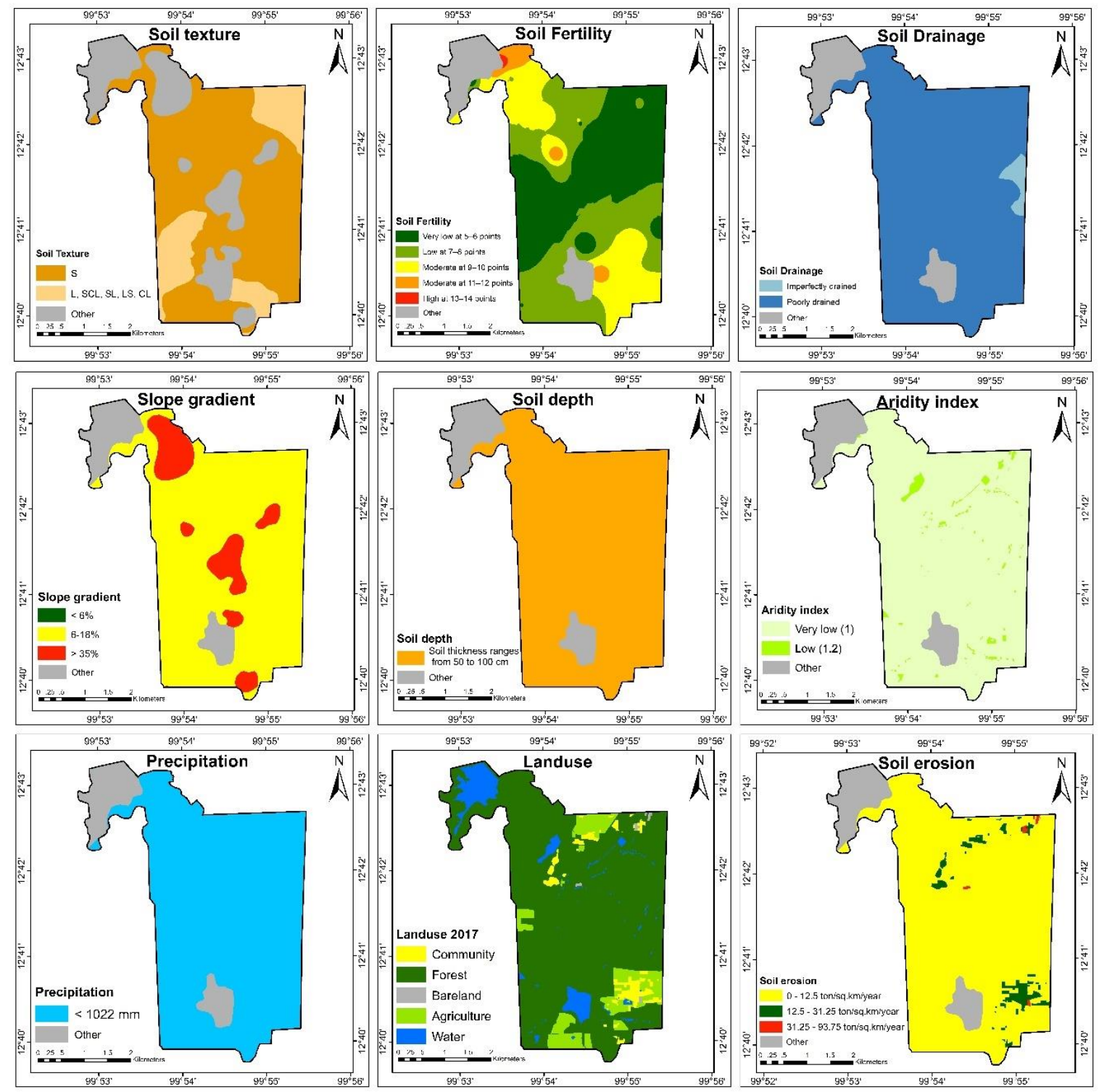

Figure 3. Map of the desertification risk factors.

This study (2017) showed that there had been a marked change in the land use since 2010: in 2017, the agricultural area increased to $16.16 \%$ when compared to the agricultural area in 2010, while the forest area slightly increased by $0.03 \%$. Moreover, bare land significantly decreased to $48.53 \%$ when compared to the bare land in 2010 . The land usage in 2010, which would cause an increase in the atmospheric humidity, decreased temperature [39,40], and better-maintained soil moisture [41,42] in the area. Moreover, an increase in the forest area helps to reduce soil erosion [11,12,43], while the increased soil fertility, another factor that affects the deterioration of the area and causes desertification, leads to a decreased drought and desertification risk. The study agreed well with the previous result [8] that changing the land use, in both pattern and sizing, affects the risk of soil erosion. The greatest area (36.52\%) in 2017 had very low soil fertility while most of the soil fertility in 2010 was highly fertile. In desertification risk between 2010 and 2017, the areas at severe risk were decreased at 44\%, high risk $(38.78 \%)$, and low risk $(66.57 \%)$. The moderate risk was increased. According to spatial analysis of desertification risk, it was found that the area at high risk had a low to very low fertile soil, which was covered by Deciduous dipterocarp forest. 


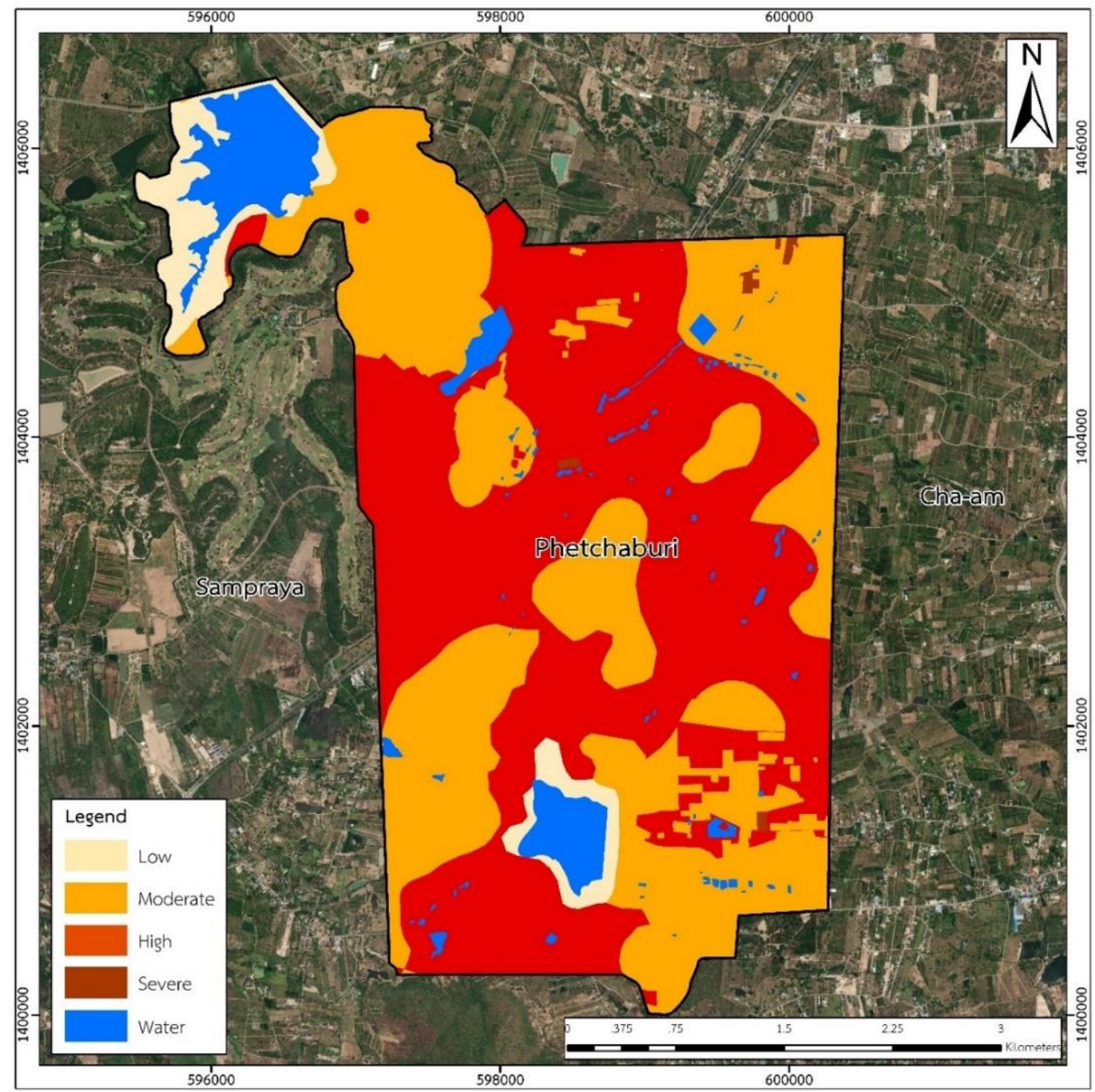

Figure 4. Map of the Desertification Risk in Huay Sai in 2017.

\subsection{The Restoration Plan Area: Land-Soil-Water Management at Huay Sai}

The HSRDSC has followed a continuous management, development, and area restoration plan that consists of the five key development plans, which are the development of the (i) soil resources, (ii) water resources, (iii) forest restoration, (iv) renewable energy, and (v) quality of life. Thus, the assessment of the spatial management to reduce the desertification risk considered the Huay Sai strategic plan for the areas in relation to factors influencing the desertification risk. The development and restoration of Huay Sai has been closely following the late King Bhumibol Adulyadej's royal advice, which provided guidelines to solve the problems by integrating the restoration of the soil, forests, and water together in order to restore the ecosystem.

The restoration of infertile soil and water resources was performed by hydrating the soil using check dams, diversion, and terracing, the late King's royal initiative, in appropriate areas. Vetiver (Chrysopogon zizanioides) has also been planted in order to help restructure the hard and compact soil. Vetiver grass is planted in an upside-down V-shape $(\wedge)$ along the slopes and in a semicircle-shape in the flat areas for planting fruit trees. However, since the soil in the area was too hard and compact to work with a hoe, it was drilled prior to planting the vetiver grass. Moreover, the horizontal spread of the vetiver roots was used to set the distance between rows for planting. Vetiver grass does not need much care and cost for growing since it is very low.

The processes of "Reforestation without Planting" and "Wet Mountain" were used to restore the forests. Late King Bhumibol Adulyadej recommended that reforestation be conducted according to 
geographical and environmental conditions. These involved growing plant varieties in the original forest area to enhance biodiversity. Local plants species which suitable for the area were planted. Forests should be grown on hilltops as degraded forests at higher altitudes affect basins downstream. Trees with seed pods should be planted so that natural regeneration occurs downhill through to the bottom of the hill. Spermatophytes are planted on the highest locations because their seeds would float down and germinate in the lower areas when these trees grow up would be naturally propagated. Moreover, water was pumped up, using solar energy, from nearby reservoirs and stored in tanks located on the hills. The water was then allowed to spill over the surrounding areas to nourish the fast-growing economic and indigenous species of trees in the area. This forest restoration method enabled a high survival rate of the plants together with the development of a network of four constructed reservoirs. Indigenous plant species were planted in the area, including Pterocarpus indicus Willd., Shorea obtuse, Shorea siamensis, Sindora siamensis Teijsm. Ex Miq., Afzelia xylocarpa (Kurz) Craib, Yellow Flame, etc. Moreover, the HSRDSC also emphasizes agrochemical-free farming and growing more indigenous crops.

Nowadays, the development and land management of the area still follows the late King's advice closely. The master plan of the HSRDSC has been used as a guideline for development in the same five strategies of the development plan as mentioned above, are implemented together as a year-by-year plan. The review of the 35-year strategic plan of the HSRDSC revealed that two strategies are closely related to reducing the drought and desertification risk of the area. These strategies are the study, research, and implementation of the royal initiatives and the conservation and development of natural resources and the environment. The analysis of the plan and mitigations, including the relation to factors influencing desertification, is shown in Table 4.

Table 4. Plan and mitigations of the HSRDSC and the relation to desertification factors.

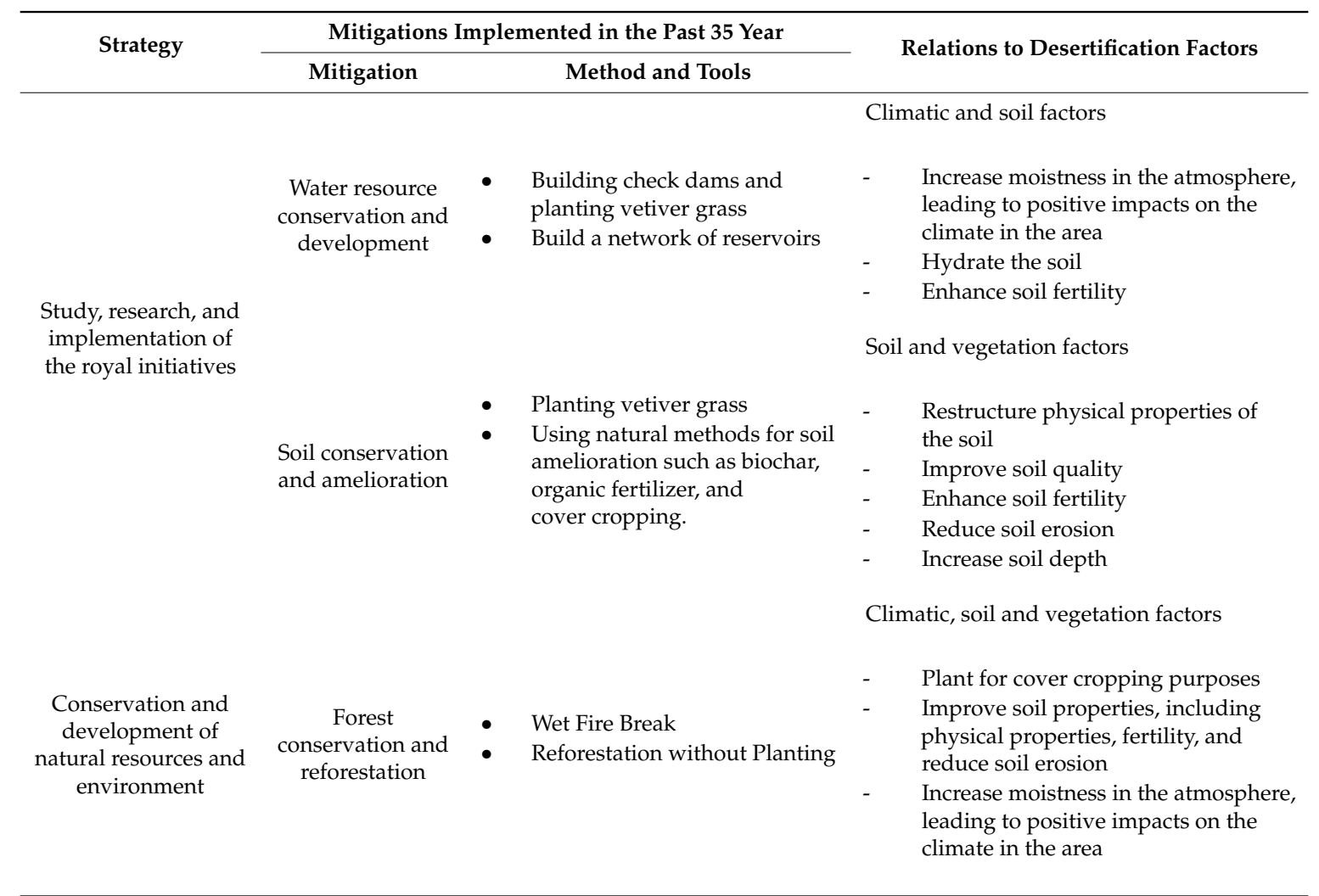

\subsection{Reducing the Desertification Risk in Huay Sai by Implementing Spatial Management Mitigations}

The desertification risk assessment in the case of application of the three mitigations showed that it was significantly decreased. Following the complete implementation of the three mitigations (to more 
than $75 \%$ of the total area), the areas with severe and high risk of desertification disappeared. Instead, most areas were of a moderate $(61.04 \%)$ or low $(32.43 \%)$ desertification risk (Table 5 and Figure 5). This change had a marked impact on the soil, drought, and desertification process in the area.

Table 5. Risk levels of the area with and without area restoration.

\begin{tabular}{ccc}
\hline Severity Levels & \multicolumn{2}{c}{ Areas at Risk of Desertification $\mathbf{( k m}^{\mathbf{2}} \mathbf{~}$} \\
\cline { 2 - 3 } & Without Mitigations & With Mitigations \\
\hline Low & 0.880 & 5.973 \\
Moderate & 7.580 & 11.241 \\
High & 8.706 & 0.000 \\
Severe & 0.048 & 0.000 \\
\hline
\end{tabular}

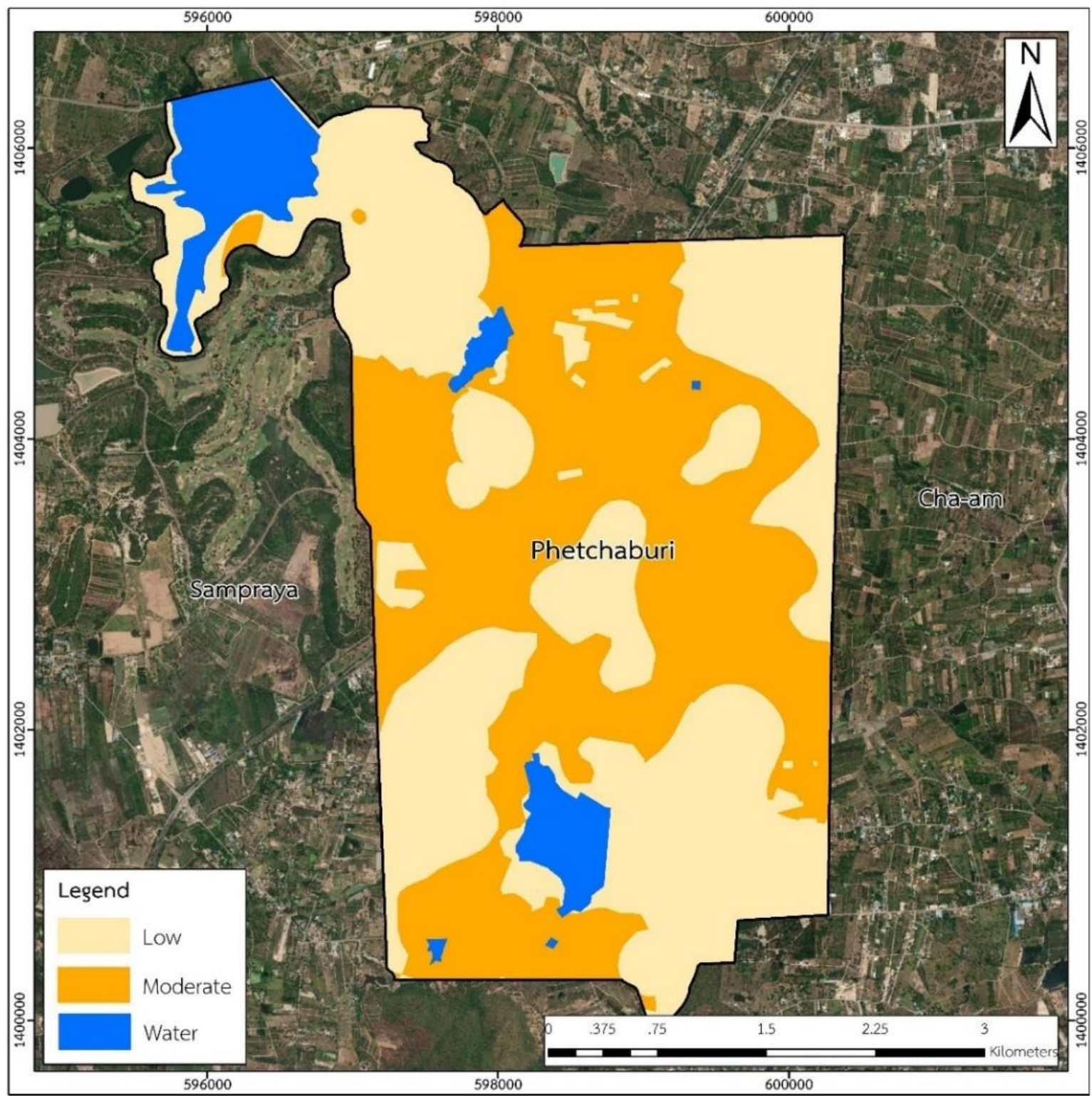

Figure 5. Risk in Huay Sai When All Three Restoration Mitigations are Applied.

These three mitigations (measures) aimed to restore the soil and water resources, the absence of which are the two main sources of desertification. Measure 1 was to develop the water resources and conserve the soil by building reservoirs and planting vetiver grass. Measure 2 was to restore the soil 
resources by soil amelioration and planting vetiver grass, while measure 3 was reforestation. The three mitigations together formed a complete integration for restoring all the connected natural resources, including water, soil, and forest resources, and mainly led to the restoration of the ecological and hydrological system in the area. This is because the water sources moisturize the soil and atmosphere, while the forest decreases the soil erosion, increases soil fertility, modifies the soil structure, and restores the soil resources. Using soil amelioration techniques, such as the addition of biochar, green manure, and organic fertilizer, increases the soil fertility and makes crop cultivation and plant cover easier. This then helps the soil keep its moisture and fertility, reduces soil erosion, and increases the soil depth, which are main factors for reducing the drought and desertification risk.

Planting vetiver grass to modify the soil structure and drought in the area has been performed since 1992 and has effected the restoration of the physically-degraded, hard, and compact soil that was unable to absorb water, as well as improved the chemical properties of soil (i.e., reduced acidity and increased fertility). Vetiver grass, a monocotyledon xerophyte, has a wide climate and environmental tolerance, fast growth, and a strong suitable structured root system comprised of a massive fine network that grows some 1-1.5 $\mathrm{m}$ deep into the soil rather than mainly spreading horizontally $[28,40,44,45]$. However, in the Doi Tung Development Project (under royal patronage) [29] it was reported that the vetiver roots penetrated the soil by up to $5.2 \mathrm{~m}$ below the surface, growing $3 \mathrm{~m}$ deep within 8 months. Moreover, vetiver grass helps to absorb contaminating chemical residues in the soil (bioremediation) from the long-term usage of agrochemicals in monocotyledon cultivation. Then, the contaminated soil with agrochemical in the area was treated. Vetiver grass planting for soil restoration is generally performed in contaminated [29,46,47] and soil-eroded [44] areas. Vetiver roots reduce the cohesion of the shear strength of soil [44] and reduce the water losses in soil [45], leading to a better absorption of water in the soil.

Although many research studies have found that vetiver have strong roots system, there have not been many studies on using vetiver grass in hard and compact soils to remedy the soil structure. Vetiver has a deep-penetrating root system, spreading out to form an underground wall barrier, which helps to filter silt and keep topsoil very well. Vetiver roots penetrates vertically into the soil as a semisolid wall-like structure. This formation helps trap debris and prevents erosion of surface soil. According to innovative techniques to plant vetiver grass, with their strong root system growing deep down and massive fine root network structure, they are able to grow through the hardpan soil. They help in the conservation of both soil and water. Their extensive fibrous root system will absorb large amounts of water, which helps in moistening the surrounding soil, thus making soil cultivable to other trees. Moreover, using vetiver hedges as a source of mulching material also helps to keep moisture in the soil by suppressing weed growth and thus reducing loss through transpiration.

The HSRDSC was one of the prototypes to restore the critically degraded soil resources in the area back to usable soil. Infertile acid soil in the area needed suitable amendment by appropriate methods for improvement. Moreover, the hardpan soil in Huay Sai area needed an appropriate method for restoration. The restoration idea was derived from the royal initiation of His Majesty King Bhumibol Adulyadej. The hardpan infertile soil was revived with innovative methods using vetiver grass as a living natural wall, grown in dug-out holes filled with soil containing fertilizer and moisture.

In the agricultural areas, the soil was restored and maintained by the application of biochar, biofertilizer, and green manure as soil amendments, which effectively helped the soil restoration. Various studies have reported that biochar addition can improve the physical structure of soil (e.g., [48-50]). In addition, it improves the water retention and ventilation of the soil and gives it a loamier structure. The biochar also reduced the acidity of the soil, increased the cation exchange capacity and the fertility of soil, and favored the colonization and activity of soil bacteria [48-50]. Together, these led to improved soil properties for crop planting so the area had vegetation cover over the soil. Moreover, multicropping systems and crop diversification were promoted to maximize productivity.

It is known that reforestation is one of the main factors to protect the environment and reduce drought $[10,36,42,51]$. Even the link between the forest and the drought from desertification is 
complicated due to various factors, such as the type and structure of the forest [51], species of plants [39-41], and climate [14,52]. This is because the reforestation increases the soil moisture [11,36, $40,41,44,53]$, and the plant roots help to cling and hold soil and so increase the soil particle adhesion. Plants require enough amount of moisture and precipitation to grow, which depends on tree types, climate, soil, topography, and ecological system. However, increasing the evapotranspiration from high temperature and extreme drought effect on land restoration and reforestation management [53], especially in drought area and degraded area. In this case, forest water use was likely supported by groundwater or seeping water sources from surrounding areas $[53,54]$. Following the path of the wisdom of the Monarch, the late King Bhumibol Adulyadej's royal developed a multipurpose reforestation model and a cultivation system that supports reforestation efforts to rehabilitate the infertile land suffering from prolonged droughts. Forest encroachers have willingly taken part in the rehabilitation, which is in harmony with nature, and this has helped improve their livelihood. In solving spatial drought problems of the Huay Sai, Royal Development Study Center is operated by a method called "Reforestation without Planning". In the mountain areas of bald mountain, "Wet Forest System" is a method of forest restoration that creates water weir to increase soil moisture, creating a small reservoir on the mountain and connecting the water distribution system to provide water to the plants around the areas. The reforestation method enabled a high survival rate of the plants and helped to provide moisture in the surrounding areas. The area around a small reservoir on the mountains will be planted with a variety of trees. The selected variant of trees will conserve the indigenous plant species. When these trees grow, the seeds will fall below while the area below has been moisturized from the water pipeline distribution system. The seeds will grow, and the trees planted with the above methods will be strong and have a high survival rate due to the germination of seeds in the environment. It can be said that planting trees in this method is a way to imitate nature. Following the forest conservation and reforestation mitigation, the forest areas in Huay Sai have become more fertile. There are approximately 800 hectares of mixed deciduous forest covering about $46 \%$ of the total area. Therefore, management and planning methods for reforestation in this condition should be adjusted appropriately and suit the local conditions.

Moreover, HSRDSC launched campaigns and programs to build the understanding and recognition of the value and benefits of the natural resources among the local people. HSRDSC aims to ensure the success of the resettlement program, which will lead to improvement of the socioeconomic conditions and quality of life of the people. This entails developing the community to become strong so that the people can be self-reliant.

\subsection{Implications to Achieve the Degradation Neutrality}

Land degradation and desertification affect ecosystem service, socio-economics, food security, and quality of human life. It can be said that degradation of land and desertification is a real challenge to the citizens of the world. The United Nations set 17 targets for Sustainable Development Goals. The SDG target 15.3 calls on countries to "combat desertification, restore degraded land and soil, including land affected by desertification, drought and floods, and strive to achieve a land degradation-neutral world". This target is focused on the sustainable management and restoration of the lands.

Land degradation is substantial in occurrence in the Huay Sai area. The abundant natural resources in the Huay Sai area ware degraded by human activities. Rehabilitation of the Huay Sai area is an example of spatial measures to solve land degradation problems. The success of the Huay Sai area rehabilitation is due to many factors, including understanding the source points of the problems, systematic thinking, nature-based solutions, having an organization with clear responsibility, continuous implementation of the measures, and communities' awareness-raising. Planning and implementation for rehabilitation must take account of the local environment in terms of the physicochemical environment, the socioeconomic environment, and the cultural environment. The development of the land and area restoration plan is established based on an understanding of the area's ecosystem and the connection of natural resources (soil-water-forest). The approach is also 
multidisciplinary in nature with various participatory actors. In terms of organization, the HSRDSC acts as the core unit for implementing, monitoring, and coordination in project planning, implementation, and management among different government agencies within an inter-sectoral framework in order to render the work effective. Rehabilitation of land and restoration of natural resources takes more than 30 years. Although the rehabilitation by the way of the late King Bhumibol Adulyadej usually takes time, it is reasonable and sustainable. Times are crucial for sustainability since adjustment as the result of various factors needs time intervals in adjusting to reach another equilibrium.

Finally, research on desertification risk assessment and analysis of ways to reduce those risks is difficult and complex, especially in a small area. However, such research is very necessary, and it is crucial to take steps to achieve sustainable development.

\section{Conclusions}

The study indicated that most areas in the Huay Sai study area were at high risk of desertification. The areas sensitive to desertification were identified by three sensitivity indexes: soil, climate, and vegetation. The critical factors affecting the desertification risk were the soil texture and fertility and the land-use factor. The mitigations for restoration were water resource conservation and development, soil conservation and amelioration, and forest conservation and reforestation. The implementation of all three mitigations had a positive impact on the area in terms of reducing the severe and high risk-of-desertification areas and distinctly positive impacts on areas with a moderate and low risk of desertification. The aforementioned mitigations led to a more fertile area. The drought and degraded land showed a significant improvement. In summary, measures to reduce the risk for desertification and drought should consider the main factors that cause the problem. Solving each environmental problem at its source point could help decrease drought and desertification in the area. The success of the area restoration was due to the use of appropriate methods to address the area-specific problems, as well as the consistency between the restoration integration and the spatial problem.

Author Contributions: Conceptualization, S.W.; data curation, S.W.; formal analysis, S.W.; investigation, S.W.; methodology, S.W.; validation, S.W.; writing-original draft, S.W.; writing-review and editing, S.W. All authors have read and agreed to the published version of the manuscript.

Funding: The research was funded by the Higher Education Research Promotion and National Research University Project of Thailand, Office of the Higher Education Commission (CC315A). Additionally, the research was also partially supported by the "Innovation in Increasing the Organic Carbon in Soil for Sustainable Agricultural Purpose in Saline Soil Areas: First Year Pilot Project at the Lam Ta Kong Watershed", Ratchadaphisek Somphot Endowment Fund (2014), Chulalongkorn University (CU-57-090-IC).

Conflicts of Interest: The authors declare no conflict of interest.

\section{References}

1. UNISDR. Progress and Challenges in Disaster Risk Reduction: A Contribution towards the Development of Policy Indicators for the Post-2015 Framework on Disaster Risk Reduction; United Nations Publication: Geneva, Switzerland, 2014.

2. UNCCD. Committee for the Review of the Implementation of the Convention. In Review of the Report on Enhanced Implementation of the Obligations of the Convention, Fourth session; Nairobi, Kenya, 18-21 October 2005.

3. UNCCD. Climate Change and Desertification; United Nations Convention to Combat Desertification: Bonn, Germany, 2016.

4. Wijitkosum, S. The impact of land use and spatial changes on desertification risk in degraded areas in Thailand. Sustain. Environ. Res. 2016, 26, 84-92. [CrossRef]

5. UNSO. Drought Preparedness and Mitigation in Sub-Saharan Africa; United Nations Office to Combat Desertification and Drought: New York, NY, USA, 1999.

6. Reynolds, J.; Stafford Smith, M. Global Desertefication: Du Human Cause Deserts; Reynolds, J., Stafford Smith, M., Eds.; Dahlem University Press: Dahlem, German, 2002; p. 438.

7. Adeel, Z.; Safriel, U.; Niemeijer, D.; White, R. Millenium Ecosystem Assessment (MEA). In Ecosystems and Human Well-Being: Desertification Synthesis; World Resources Institute: Washington, DC, USA, 2005. 
8. Bestelmeyer, B.T.; Okin, G.S.; Duniway, M.C.; Archer, S.R.; Sayre, N.F.; Williamson, J.C.; Herrick, J.E. Desertification, land use, and the transformation of global drylands. Front. Ecol. Environ. 2015, 13, 28-36. [CrossRef]

9. Wijitkosum, S. Critical Factors Affecting the Desertification in Pa Deng, Adjoining Area of Kaeng Krachan National Park, Thailand. EnvironmentAsia 2014, 7, 87-98.

10. García-Ruiz, J.M. The effects of land uses on soil erosion in Spain: A review. Catena 2010, 81, 1-11. [CrossRef]

11. Wijitkosum, S. Impacts of land use changes on soil erosion in Pa Deng sub-district, adjacent area of Kaeng Krachan National Park, Thailand. Soil Water Res. 2012, 7, 10-17. [CrossRef]

12. Cotler, H.; Ortega-Larrocea, M.P. Effects of land use on soil erosion in a tropical dry forest ecosystem, Chamela watershed, Mexico. Catena 2006, 65, 107-117. [CrossRef]

13. Wu, R.; Tiessen, H. Effect of land use on soil degradation in Alpine Grassland soil, China. SSSAJ 2002, 66, 1648-1655. [CrossRef]

14. Feng, Q.; Ma, H.; Jiang, X.; Wang, X.; Cao, S. 2015. What has caused desertification in China? Sci. Rep. 2015, 5, 15998. [CrossRef]

15. Cerdà, A.; Rodrigo-Comino, J.; Novara, A.; Brevik, E.C.; Vaezi, A.R.; Pulido, M.; Keesstra, S.D. Long-term impact of rainfed agricultural land abandonment on soil erosion in the Western Mediterranean basin. Prog. Phys. Geogr. Earth Environ. 2018, 42, 202-219. [CrossRef]

16. Cerdà, A.; Ackermann, O.; Terol, E.; Rodrigo-Comino, J. Impact of farmland abandonment on water resources and soil conservation in citrus plantations in eastern Spain. Water 2019, 11, 824. [CrossRef]

17. Keesstra, S.; Mol, G.; de Leeuw, J.; Okx, J.; de Cleen, M.; Visser, S. Soil-related sustainable development goals: Four concepts to make land degradation neutrality and restoration work. Land 2018, 7, 133. [CrossRef]

18. Keesstra, S.D.; Bouma, J.; Wallinga, J.; Tittonell, P.; Smith, P.; Bardgett, R.D. The significance of soils and soil science towards realization of the United Nations Sustainable Development Goals. Soil 2016, 2, 111-128. [CrossRef]

19. Kosmas, C.; Kirkby, M.J.; Geeson, N. The Medalus Project: Mediterranean Desertification and Land Use: Manual on Key Indicators of Desertification and Mapping Environmentally Sensitive Areas to Desertification; Directorate-General Science, Research and Development; Springer: Dordrecht, Netherland, 1999.

20. Bouabid, R.; Rouchdi, M.; Badraoui, M.; Diab, A.; Louafi, S. Assessment of land desertification based on the MEDALUS approach and elaboration of an action plan: The case study of the Souss River Basin, Morocco. In Land Degradation and Desertification: Assessment, Mitigation and Remediation, 1st ed.; Zdruli, P., Pagliai, M., Kapur, S., Faz Cano, A., Eds.; Springer: Dordrecht, Netherlands; Heidelberg, Germany, 2010; pp. 131-145.

21. Salvati, L.; Scarascia, M.E.V.; Zitti, M.; Ferrara, A.; Urbano, V.; Sciortino, M.; Giupponi, C. The integrated assessment of land degradation. Ital. J. Agron. 2009, 4, 77-90. [CrossRef]

22. Sepehr, A.; Hassanli, A.M.; Ekhtesasi, M.R.; Jamali, J.B. Quantitative assessment of desertification in south of Iran using MEDALUS method. Environ. Monit. Assess. 2007, 134, 243-254. [CrossRef]

23. Ladisa, G.; Todorovic, M.; Liuzzi, G.T. A GIS-based approach for desertification risk assessment in Apulia region, SE Italy. Phys. Chem. Earth. 2012, 49, 103-113. [CrossRef]

24. Masoudi, M.; Zakerinejad, R. Hazard assessment of desertification using MEDALUS model in Mazayjan plain, Fars province, Iran. Ecol. Environ. Conserv. 2010, 16, 425-430.

25. Farajzadeh, M.; Egbal, M.N. Evaluation of MEDALUS model for desertification hazard zonation using GIS; study area: Iyzad Khast plain, Iran. Pak. J. Biol. Sci. 2007, 16, 2622-2630.

26. Leman, N.; Ramli, M.F.; Khirotdin, R.P.K. GIS-based integrated evaluation of environmentally sensitive areas (ESAs) for land use planning in Langkawi, Malaysia. Ecol. Indic. 2016, 61, 293-308. [CrossRef]

27. Land Development Department. Kingdom of Thailand National Action Programme for Combating Desertification; Ministry of Agriculture and Coorperative: Bangkok, Thailand, 2004; p. 33.

28. Sherwood, S.; Fu, Q. A Drier Future? Science 2014, 343, 737-739. [CrossRef]

29. Wijitkosum, S. A monarch's Forest restoration project: Drought management strategies. Unisearch J. Spec. Ed. 2017, 42-55.

30. Wijitkosum, S.; Yolpramote, K. Clustering soil properties for appropriate soil improvement in Huay Sai Royal Development Study Center, Thailand. In Proceedings of the 6th TSAE International Conference, Prachuapkhirikhan, Thailand, 1-4 April 2013; pp. 175-178.

31. UNCCD. Combating Desertification and Land Degradation: Proven Practices from Asia and the Pacific; Republic of Korea: Changwon, Korea, 2011; p. 244. 
32. Adamo, S.B.; Crews-Meyer, K.A. Aridity and Desertification: Exploring Environmental Hazards in Jáchal, Argentina. Appl. Geogr. 2006, 26, 61-85. [CrossRef]

33. Gibbs, W.J.; Maher, J.V. Rainfall Deciles as Drought Indicators; Bulletin no. 48; Bureau of Meteorology: Melbourne, Australia, 1967.

34. Allen, R.G.; Pereira, L.S.; Raes, D.; Smith, M. Crop Evapotranspiration-Guidelines for Computing Crop Water Requirements-FAO Irrigation and Drainage Paper 56; Food and Agriculture Organization of the United Nations: Rome, Italy, 1998.

35. Food and Agriculture Organization of United Nations. The ETo Calculator: Evapotranspiration from a Reference Surface; Reference Manual Version 3.1; Food and Agriculture Organization of the United Nations, Land and Water Division: Rome, Italy, 2009.

36. Parks, C.G.; Bernier, P. Adaptation of forests and forest management to changing climate with emphasis on forest health: A review of science, policies and practices. For. Ecol. Manag. 2010, 259, 657-659. [CrossRef]

37. Zhao, Y.; Xu, X.; Sun, W.; Huang, B.; Darilek, J.; Shi, X. Uncertainty assessment of mapping mercury contaminated soils of a rapidly industrializing city in the Yangtze River Delta of China using sequential indicator co-simulation. Environ. Monit. Assess. 2008, 138, 343-355. [CrossRef] [PubMed]

38. Gray, D.H.; Leiser, A.T. Biotechnical Slope Protection and Erosion Control; Van Nostrand Reinhold: New York, NY, USA, 1982.

39. Lopez-Iglesias, B.; Villar, R.; Poorter, L. Functional traits predict drought performance and distribution of Mediterranean woody species. Acta Oecol. 2014, 56, 10-18. [CrossRef]

40. Hoffmann, W.A.; Marchin, R.M.; Abit, P.; Lau, O.L. Hydraulic failure and tree dieback are associated with high wood density in a temperate forest under extreme drought. Glob. Chang. Biol. 2011, 17, 2731-2742. [CrossRef]

41. Anderegg, L.D.; HilleRisLambers, J. Drought stress limits the geographic ranges of two tree species via different physiological mechanisms. Glob. Chang. Biol. 2016, 22, 1029-1045. [CrossRef]

42. Wei, L.; Zhang, D.; Xiang, F.; Zhang, Z. Differentially expressed miRNAs potentially involved in the regulation of defense mechanism to drought stress in maize seedlings. Int. J. Plant Sci. 2009, 170, 979-989. [CrossRef]

43. Zhou, P.; Luukkanen, O.; Tokola, T.; Nieminen, J. Effect of vegetation cover on soil erosion in a mountainous watershed. Catena 2008, 75, 319-325. [CrossRef]

44. Truong, P. Vetiver grass system: Potential applications for soil and water conservation in northern California. In Proceedings of the Stiff Grass Technology Seminar, sponsored by the Yolo County Flood Control \& Water Conservation District and Family Water Alliance, Woodland, CA, USA, 9 May 2000; pp. 562-571.

45. Lavania, U.C.; Lavania, S. Vetiver grass technology for environmental protection and sustainable development. Curr. Sci. 2000, 78, 944-946.

46. Wong, M.H. Ecological restoration of mine degraded soils, with emphasis on metal contaminated soils. Chemosphere 2003, 50, 775-780. [CrossRef]

47. Chen, C.R.; Condron, L.M.; Davis, M.R.; Sherlock, P.R. Effects of afforestation on phosphorus dynamics and biological properties in a New Zealand grassland soil. Plant Soil 2000, 220, 151-163. [CrossRef]

48. Sriburi, T.; Wijitkosum, S. Biochar Amendment Experiments in Thailand: Practical Examples. In Biochar a Regional Supply Chain Approach in View of Climate Change Mitigation, 1st ed.; Bruckman, V.J., Varol, E.A., Uzun, B.B., Liu, J., Eds.; Cambridge University Press: Cambridge, UK, 2016; pp. 351-367.

49. Wijitkosum, S.; Kallayasiri, W. The Use of Biochar to Increase Productivity of Indigenous Upland Rice (Oryza sativa L.) and Improve Soil Properties. Res. J. Pharm. Biol. Chem. Sci. 2015, 6, 1326-1336.

50. Lehmann, J.; Joseph, S. Biochar for environmental management: An introduction. In Biochar for Environmental Management: Science and Technology; Earthscan: London, UK, 2009.

51. McDowell, N.; Pockman, W.T.; Allen, C.D.; Breshears, D.D.; Cobb, N.; Kolb, T.; Plaut, J.; Sperry, J.; West, A.; Williams, D.G.; et al. Mechanisms of plant survival and mortality during drought: Why do some plants survive while others succumb to drought? New Phytol. 2008, 178, 719-739. [CrossRef] [PubMed]

52. McDowell, N.G.; Beerling, D.J.; Breshears, D.D.; Fisher, R.A.; Raffa, K.F.; Stitt, M. The interdependence of mechanisms underlying climate-driven vegetation mortality. Trends Ecol. Evol. 2011, 26, 523-532. [CrossRef]

53. Mátyás, C.; Sun, G. Forests in a water limited world under climate change. Environ. Res. Lett. 2014, 9, 085001. [CrossRef] 
54. Feng, X.; Fu, B.; Piao, S.; Wang, S.; Ciais, P.; Zeng, Z.; Lü, Y.; Zeng, Y.; Li, Y.; Jiang, X.; et al. Revegetation in China's Loess Plateau is approaching sustainable water resource limits. Nat. Clim. Chang. 2016, 6, 1019-1022. [CrossRef]

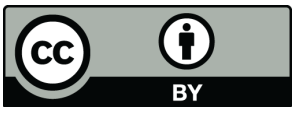

C) 2020 by the author. Licensee MDPI, Basel, Switzerland. This article is an open access article distributed under the terms and conditions of the Creative Commons Attribution (CC BY) license (http://creativecommons.org/licenses/by/4.0/). 